УДК $621.593 ; 665.60$

DOI: $10.33070 /$ etars.1.2021.04

Braverman V.Ya. ${ }^{1}$, Candidate of Technical Sciences, Krusch I.B. ${ }^{1}$, Savchuk S.D. ${ }^{2}$

${ }^{1}$ LLC «Consulting and Implementation Center "Renezable Resources" 》, Odessa 10-b, Marshal Govorov Str., 65059 Odessa, Ukraine, e-mail: braverman@resources.odessa.ua

${ }^{2}$ Company «Clear Energy», Kiev region, Ukraine

2, Sobornaya Str., p. Petropavlovskaya Borschagovka, Kiev region, Ukraine, e-mail: sdsavchuk74@gmail.com

\title{
Hydrogen Production System from the Organic Part of the Odessa Landfill Solid Waste
}

\begin{abstract}
System of hydrogen production from the organic part of solid household waste, typical for the landfill of the city of Odessa is discussed. The system consists of low-temperature waste pyrolysis, high-temperature gasification of pyrolysis products, as well as a unit for membrane separation of synthesis gas into pure hydrogen and carbon monoxide. The high efficiency of the system we offer is achieved due to the recovery of the exothermic heat of the process, as well as combustion of carbon monoxide obtained during the separation of synthesis gas. The Odessa landfill receives solid waste per year from 2.5 million $\mathrm{m}^{3}$ to 3.0 million $\mathrm{m}^{3}$ depending on the season. Accordingly, up to 1.0 million $\mathrm{m}^{3}$ or 157,000 tons of carbon-containing (biodegradable) waste is subject to energy processing. With a minimum selling price of hydrogen of $\$ 4 / \mathrm{kg}$, the annual income from the sale of 15,700 tons will be $\$ 62.8$ million. Bibl. 11, Fig. 3, Table 1.
\end{abstract}

Key words: hydrogen, municipal solid waste, accumulation, pyrolysis, gasification, organic Rankine cycle.

The formation of such an important area of modern energy as hydrogen energy dates back to the mid 70 s of the last century. It was based on the production of hydrogen from water by thermochemical methods with the energy supply of the process with the heat of nuclear fast reactors with a high-temperature coolant. However, this direction did not receive its development due to the negative attitude towards the operation of nuclear power plants, which was facilitated by large-scale accidents at these facilities (Chernobyl, Fukushima). Nevertheless, as the main field of application of the obtained hydrogen, it was supposed to be used in transport in hybrid engines with electrochemical generators - fuel cells that use the reaction of hydrogen oxidation with air, and in internal combustion engines of hydrocarbon fuel.

The current stage in the development of hydrogen energy should be considered as a result of the implementation of the European Union concept, approved in January 2009 by the European Commission as a new "environmental and energy package", which in 2010 became the "20-20-20" program. One of the provisions of this program pro- vides for the achievement by 2020 in the countries of the European Union of $20 \%$ of the share of renewable energy resources (RES) in total energy consumption, and the program is planned to be extended until 2035, and in recent years the "hydrogen direction" has been recognized as one of the leading [1].

A detailed analysis of the options for the possible use of hydrogen obtained from renewable energy sources presented in [2] also indicates its preferable use in transport. However, it is unlikely that a hydrogen car will compete with an electric car. The emerging new trends in the use of "green hydrogen" are primarily associated with the actively developing direction of hydrogen energy storage. At the same time, researchers are interested in obtaining hydrogen from their biomass, as one of the varieties of "green hydrogen". Publication activity by types of hydrogen production technologies is presented in Fig. 1 [3].

Methods for producing biohydrogen are divided into biochemical and thermochemical. The biochemical method for obtaining $\mathrm{H}_{2}$ from the organic part of municipal solid waste is widely described 


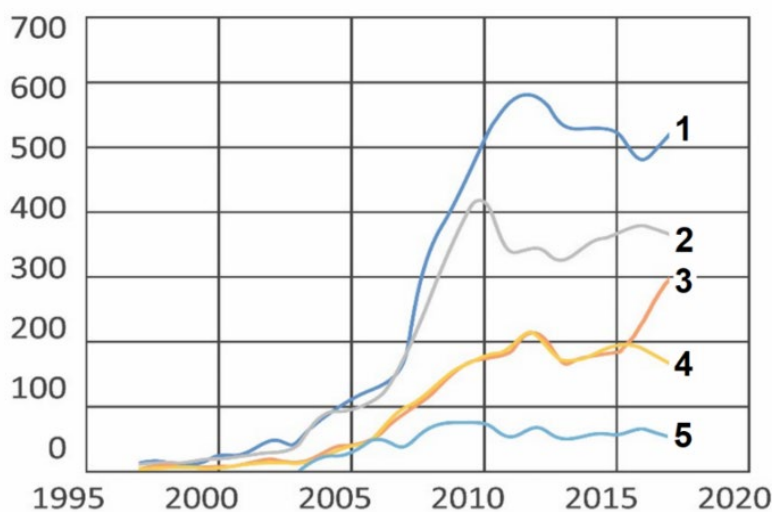

Fig. 1. Publication activity by types of hydrogen production technologies in 1997-2017: 1 - Biohydrogen; 2 - Natural gas (methane); $3-$ Electrolysis; $4-$ Biomass (without biohydrogen); 5 - Coal.

in scientific publications, for example, in $[4,5,6]$. The disadvantages of this method, despite the ap parent simplicity and low cost, is the extremely low productivity of hydrogen production units.

The thermochemical method of processing the organic part of MSW has also been widely studied, for example [7, 8], however, the purpose of the developed technologies, as a rule, is limited to the production of gaseous products of gasification (pyrolysis) or a combination of these processes to obtain fuel gas.

\section{Determination of the volume of carbon- containing waste at the Odessa solid waste landfill}

In 2019, at the Odessa solid waste landfill, Clear Energy [1] began work on installing a degassing system with capacity of up to $3 \mathrm{MW}$. In total, the company has installed 14 degassing systems at 14 landfills in different regions of the country. In accordance with the company's concept, the second stage of work at the Odessa landfill is the construction of a sorting and waste processing complex. All valuable raw materials, namely paper, plastic, wood, metal and glass, after sorting will be processed into useful products with a market value. In total, these fractions make up $60 \%$ of the volume of solid waste. Of the remaining $40 \%$ of waste, only $35 \%$ is recyclable for energy.

The morphological composition of the solid waste of the Odessa landfill is shown in Table [9].

The annual volume of solid waste supplied to the Odessa landfill, depending on the season, range from 2.5 to 3.0 million $\mathrm{m}^{3}$. Accordingly, up to 1 million $\mathrm{m}^{3}$ or 157,000 tons of carbon-containing (biodegradable) waste is subject to energy processing.

\section{Morphological composition of the solid waste of the Odessa landfill}

\begin{tabular}{|c|l|c|c|c|}
\hline No. & SW components & $\begin{array}{c}\text { Density, } \\
\mathrm{kg} / \mathrm{m}^{3}\end{array}$ & $\begin{array}{c}\text { Average } \\
\text { value by } \\
\text { weight, \% }\end{array}$ & $\begin{array}{c}\text { Average } \\
\text { value by } \\
\text { volume, } \\
\%\end{array}$ \\
\hline 1 & Food waste & 370 & 29.72 & 12.63 \\
\hline 2 & $\begin{array}{l}\text { Paper and card- } \\
\text { board }\end{array}$ & 60 & 4.80 & 12.72 \\
\hline 3 & Polymers & 45 & 13.31 & 46.02 \\
\hline 3.1 & $\begin{array}{l}\text { PET (container } \\
\text { for juices) }\end{array}$ & 27 & 3.93 & 23.18 \\
\hline 3.2 & Films and bags & 77 & 4.96 & 10.08 \\
\hline 3,3 & Other polymers & 54 & 4.43 & 12.78 \\
\hline 4 & Glass & 600 & 12.42 & 3.27 \\
\hline 5 & Black metals & 500 & 0.64 & 0.20 \\
\hline 6 & $\begin{array}{l}\text { Non-ferrous met- } \\
\text { als }\end{array}$ & 140 & 0.29 & 0.32 \\
\hline 7 & Textile & 157 & 0.36 & 0.36 \\
\hline 8 & Wood & 470 & 6.36 & 2.11 \\
\hline 9 & Hazardous waste & 102 & 0.13 & 0.20 \\
\hline 10 & $\begin{array}{l}\text { Bones, skins, rub- } \\
\text { ber }\end{array}$ & 350 & 2.79 & 1.24 \\
\hline 11 & $\begin{array}{l}\text { Combined pack- } \\
\text { ing for drinks }\end{array}$ & 85 & 0.12 & 0.22 \\
\hline 12 & The remainder & 220 & 29.46 & 21.0 \\
\hline 12.1 & $\begin{array}{l}\text { Construction } \\
\text { waste, stone }\end{array}$ & - & 6.62 & - \\
\hline 12.2 & Street trash & - & 2.01 & - \\
\hline 12.3 & Other & Total & 20.82 & - \\
\hline & - & 100.0 & 100.0 \\
\hline
\end{tabular}

\section{Hydrogen production from waste}

When choosing a technology for producing hydrogen from waste, it is necessary to proceed from an integral assessment of the technologies under consideration, taking into account economic, environmental and social aspects. Our analysis of the literature and a patent search shows that the most frequently used method of converting waste into gases is two-stage gasification. At the first stage, biomass is pyrolized, and at the second stage, the products obtained at the first stage are gasified.

In the considered two stage technologies, the final product is synthesis gas, the main components of which are $\mathrm{H}_{2}$ (hydrogen) and $\mathrm{CO}$ (carbon monoxide). Depending on the composition of the waste, the ratio of $\mathrm{CO}: \mathrm{H}_{2}$ in it varies from $1: 1$ to $1: 3$. 


\section{Highly efficient way of producing hydrogen from waste}

Our proposed two-stage highly efficient method for producing hydrogen from waste is characterized:

- by preservation and reuse of thermal energy obtained at the stages of converting waste into synthesis gas, which can significantly reduce the cost of the produced synthesis gas;

- by the presence of blocks for separating synthesis gas into hydrogen and carbon monoxide;

- by the presence of a gas boiler operating on carbon monoxide and the use of this heat to obtain superheated steam, which makes it possible to refuse from an external source of thermal energy.

Thus, the efficiency of the proposed system is achieved by recovering the exothermic heat of the pyrolysis process and combustion of carbon monoxide obtained from the waste. When developing a system for the production of pure hydrogen from the organic part of MSW, we used the developments of the authors of this article, given in $[10,11]$.

A highly efficient system for producing hydrogen from waste by low-temperature pyrolysis and high-temperature gasification in our proposed method includes equipment for grinding and dry- ing waste, a pyrolysis furnace, a gasifier, a lowtemperature heat recuperator based on materials with phase transitions, a high-temperature heat recuperator, a steam generator, a cooling system, synthesis gas cooling and purification system, a hydrogen evolution unit, a gas boiler, storage systems for hydrogen, ash and carbon dioxide.

We propose to perform the separation of hydrogen from synthesis gas using membrane units. This method of separating gaseous mixtures allows hydrogen to be separated from gas streams with minimal losses. The main advantages of membrane plants that allow hydrogen concentration include low maintenance costs, simple hardware design, and long membrane life. Fig. 2 shows a flow diagram of the interconnection of the elements of the proposed system for producing hydrogen from waste.

The technology for producing hydrogen from the biological part of municipal solid waste is implemented in the following stages:

1) shredding and drying of waste;

2) production of low-temperature and high-temperature superheated steam;

3) pyrolysis of raw materials with low-temperature water vapor at temperatures of $500-800{ }^{\circ} \mathrm{C}$ with the formation of synthesis gas, ash and coke;

4) separation of ash and coke;

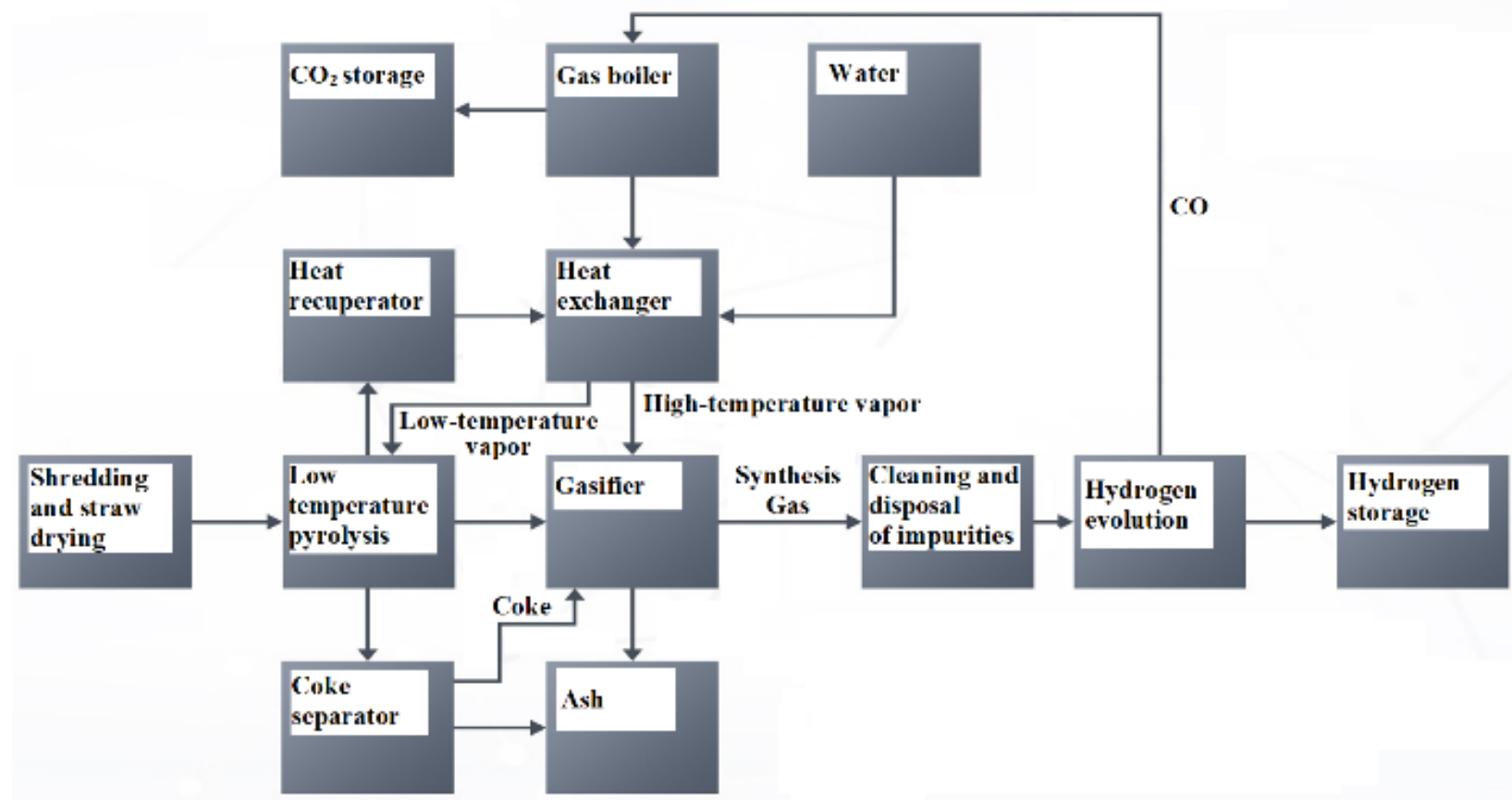

Fig. 2. Technological diagram of the interconnection of the elements of the system for obtaining hydrogen from waste. 
5) recovery of heat generated by the pyrolysis system;

6) gasification of synthesis gas and coke with high-temperature superheated steam at 1200$1600{ }^{\circ} \mathrm{C}$;

7) purification and removal of harmful impurities from synthesis gas;

8) membrane-adsorption separation of synthesis gas to produce hydrogen and carbon monoxide;

9) production of thermal energy by combustion of carbon monoxide in a gas boiler;

10) storage of carbon dioxide;

11) storage of hydrogen.

According to our proposed technology, $1 \mathrm{~kg}$ of synthesis gas can be obtained from $5 \mathrm{~kg}$ of biodegradable waste and after separation at least $0.5 \mathrm{~kg}$ of hydrogen. Accordingly, 15,700 tons of hydrogen will be obtained from 157,000 tons of biodegradable waste. With a minimum selling price of hydrogen of $\$ 4 / \mathrm{kg}$, the annual income from the sale of 15,700 tons will be $\$ 62.8$ million.

\section{Accumulation and storage of hydrogen}

The most important characteristic that determines the efficiency of hydrogen storage is its bulk and gravimetric density. From this point of view, as well as taking into account safety requirements, the most preferable method is for storing and transporting hydrogen in a bound state. This is either storage in a chemically bound form (hydrides), or storage using controlled processes of hydrogen sorption-desorption by some intermetallic compounds. The perspective of this method is determined by the following features:

- accumulation of hydrogen in hydrides used as an intermediate product during transportation and storage;

- generating hydrogen directly at the place of its consumption;

- using the principle of a battery with the possibility of multiple charging and discharging without replacing sorbents;

- the possibility of virtually unlimited in time drainless storage of hydrogen;

- relatively low pressure and temperature during operation.

Hydrides provide a high bulk density of storage: 100-150 g/1. For example, containers from Pragma Industries with a total weight of $350 \mathrm{~g}$ store 20 liters of hydrogen. Such compact, efficient and safe hydrogen storage is especially promising for systems using fuel cells.

\section{Improving energy efficiency of electric power generation, generated by fuel hydrogen cell}

The hydrogen (methane) and oxygen entering the fuel cell is converted into electricity with the release of heat. Up to $60 \%$ of this energy is converted into electrical energy, the remaining $40 \%$ is released with heat. The waste heat utilization methods used in this work were also used by us to build a system for utilizing these $40 \%$ heat. We propose to use this heat to generate additional electricity by small power plants based on the organic Rankine cycle (ORC) principle. This makes it possible to raise the conversion efficiency of hydrogen power plants to $76 \%$. To date, power plants on fuel cells of a large range in terms of capacities, up to several megawatts in one block, have already been introduced to the international markets of the USA and Europe. In practice, these systems are part of future green-fuel mass power systems. Stationary power plants based on hydrogen fuel cells have already generated more than 300 million kilowatt-hours of electricity at more than 80 stations around the world.

The technological scheme for converting waste low-grade heat generated by fuel hydrogen cells is shown in Fig. 3.

The low potential thermal energy released by the hydrogen cell is accumulated in a phase change storage tank and is then converted into electricity generated using the organic Rankine cycle (ORC). The cycle uses an organic low-boiling working fluid to create steam, which can be, for example, pentane $\left(\mathrm{C}_{5} \mathrm{H}_{12}\right)$, which, after a temperature of $+36{ }^{\circ} \mathrm{C}$, turns into a gaseous state. Examples of other organic low-boiling liquids can be hydrocarbons (butane, propane), freons (R11, R12, R114, R123, R245 + a), ammonia, toluene, diphenyl, silicone oil, etc. Initially, low potential heat from the hydrogen cell enters the storage tank, where it heats the working fluid, converting it into steam. The use of materials with a phase change in the tank allows maintaining the same temperature for a long time, which creates the preconditions for the stable operation of the system.

ORC units handle waste heat with low and medium thermal potential in the temperature range from 40 to $90{ }^{\circ} \mathrm{C}$. Further, the steam of the organic liquid enters the steam turbine, where it performs work, while the generator, located on the same shaft with the turbine, generates electricity. Thus, the incoming heat flux from the accumulator tank is transformed by the ORC into electrical energy 


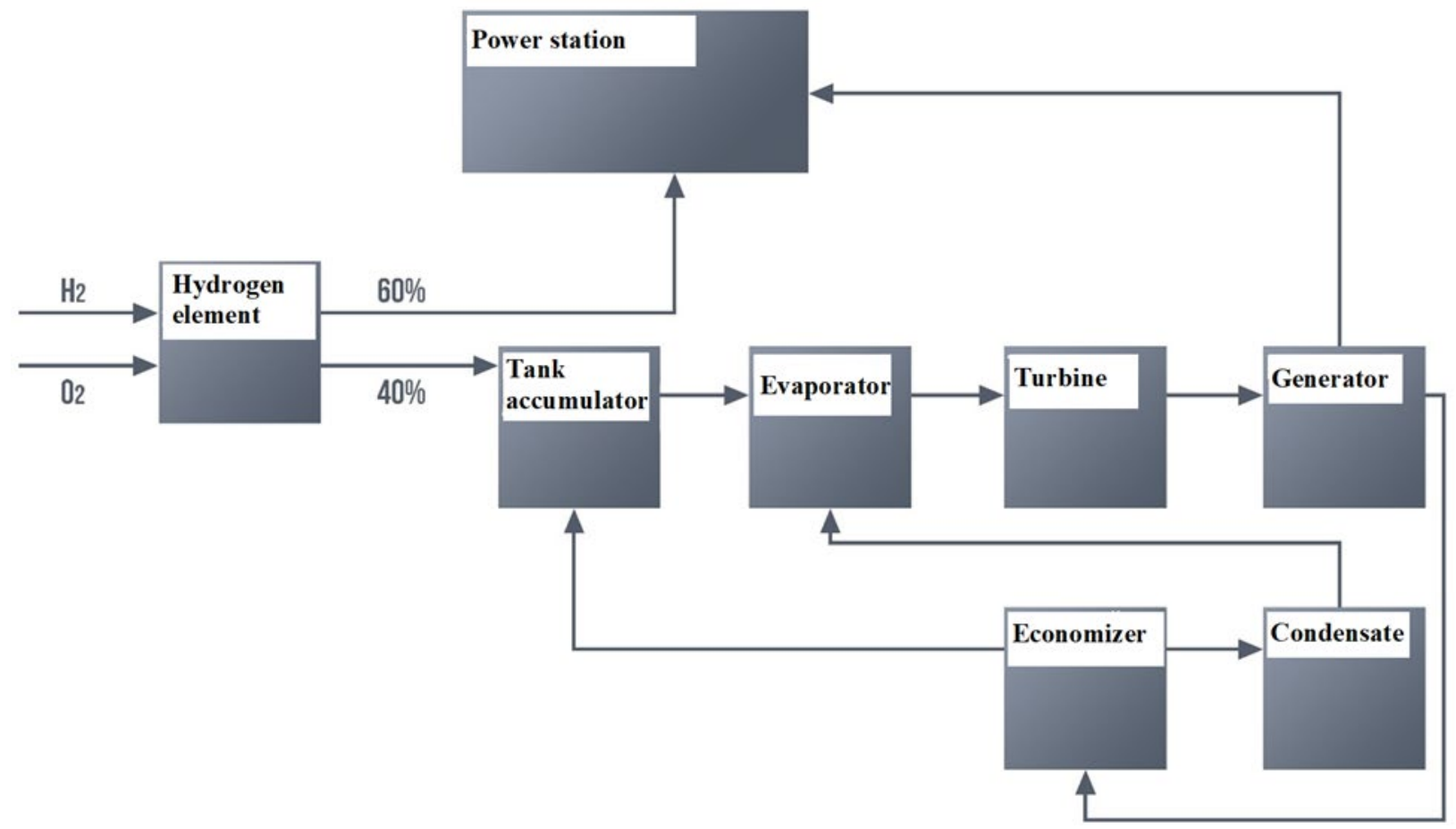

Fig. 3. Diagram of the interconnection of hydrogen fuel cells with the organic Rankine cycle.

with an efficiency of up to $25-26 \%$ and up to $75 \%$ of waste heat is also released. To increase the efficiency of the ORC, we propose that the waste heat spent after the turbine can also be used for preheating the organic working fluid. For this, a heat economizer (recuperator) is added to the cycle. After taking off the heat from the cooling circuit of the generator, steam is returned to the evaporator, where it additionally heats and evaporates the working fluid. This makes it possible to additionally accumulate thermal energy in the tank and, accordingly, increase the efficiency of the Rankine cycle by at least $10 \%$ more and bring it to $35 \%$.

\section{References}

1. Savchuk S.D. [Why Should Ukraine Stimulate Hydrogen Production Projects?] - https:// www.epravda.com.ua/rus/projects/greendeal/2020 $/ 05 / 18 / 660480 /$ (Rus.)

2. N. Armaroli, V. Balzani. The Hydrogen Issue. ChemSusChem. 2011, No. 4. pp. 21-36.

3. [Hydrogen energy technology : Federal state budgetary institution of science. Joint Institute for High Temperature of the Russian Academy of Sciences : Materials of the laboratory HET JIHT Rus. Acad. of Sci.]. Ed. D.O.Dynikov. Moscow : JIHT Rus. Acad. of Sci. 2017. Iss. 1. 190 p. (Rus.)
4. D. Sales, L. I. Romero, R. Solera. Hydrogen production from the organic fraction of municipal solid waste in anaerobic thermophilic acidogenesis: Influence of organic loading rate and microbial content of the solid waste. Bioresource Technology. February 2013. Vol. 129, pp. 85-91.

5. Jiunn-Jyi Lay, Young-Joon Lee, Tatsuya Noike. Feasibility of biological hydrogen productionfrom organic fraction of municipal solid waste. Water Research. August 1999. Vol. 33, Iss. 11, pp. 2579-2586.

6. M. Elsamadony, A. Tawfik. Potential of biohydrogen production from organic fraction of municipal solid waste (OFMSW) using pilot-scale dry anaerobic reactor. Bioresour Technol. 2015 Nov.; 196: 9-16.

7. Shen Chen, Aihong Meng, Yanqiu Long, Hui Zhou, Qinghai Li Y., and Uo Zhang. TGA pyrolysis and gasification of combustible municipal solid waste. August 2015. Vol. 88, Iss. 3. pp. 332-343.

8. Tae-Heon Kwak, Seungmoon Lee, Jin-Won Park, Sanjeev Maken, Young Done Yoo \& Sang-Houck Lee. Gasification of municipal solid waste in a pilot plant and its impact on environment. Korean J. Chem. Eng. 2006. Vol. 23, pp. 954-960. - https://doi.org/10.1007 /s11814-006-0014-2/

9. [On the provision of services for determining the morphological composition of solid waste generated in residential buildings in Odessa : Report of Ukrainian Research Institute for the Development and Implementation of Utility Programs and Projects]. LLC Kharkov, 2018. (Rus.) 
10. V.Ya.Braverman, I.B.Krush. Patent of Ukraine No. 141908 dated 27.04.2020, IPC (2020.01) C 01 B 3/02 (2006.01), C $08 \mathrm{~J} \mathrm{11/00.} \mathrm{[Technology} \mathrm{for} \mathrm{Ob-}$ taining Hydrogen from Agricultural Waste]. Publication date 27.04.2020. Bulletin No. 8. (Ukr.)
11. V.I.Kushneruk, V.Ya.Braverman, M.A.Bukraba, D.I.Chelidze. Patent of Ukraine No. 115816 dated 25.04.2017, IPC (2006.01) F 24 H 7/02. [Heat Accumulator with Phase Transition]. Publication date 25.04.2017. Bulletin No. 8. (Ukr.)

Received September 17, 2020

\author{
Браверман В.Я. ${ }^{1}$, канд. техн. наук, Круи І.Б. ${ }^{1}$, Савчук С.Д. ${ }^{2}$ \\ 1 ООО «Консалтингово-впроваджуючий центр “Відновлювальні ресурси” », Одеса \\ вул. Маршала Говорова, 10-б, 65059 Одеса, Україна, е-таil: braverman@resources.odessa.uа \\ ${ }^{2}$ Компанія «Кліар Енерджі», Київсъка область, Україна \\ вул. Соборна, 2, с. Петропавлівська Борщагівка, Київська обл., Украӥна, \\ e-mail: sdsavchuk74@gmail.com
}

\title{
Система виробництва водню з органічної частини твердих побутових відходів Одеського полігону
}

Пропонована система виробництва водню як енергоносія для водневих енергетичних технологій складається з низькотемпературного піролізу відходів, високотемпературної газифікації продуктів піролізу, а також блоку мембранного поділу синтез-газу на чистий водень та чадний газ. Висока ефективність пропонованої нами системи досягається за рахунок акумуляції бросового екзотермічного тепла піролізу в матеріалах з фазовими переходами, а також спалювання оксиду вуглецю, отриманого при поділі синтез-газу. Показано, що використання блоків акумуляції вихідного тепла на основі матеріалів з фазовими переходами у системах виробництва електричної енергії водневими паливними елементами дає можливість істотно підвищити ККд цих систем. На Одеський полігон твердих побутових відходів на рік надходить у залежності від сезону від 2,5 до 3,0 млн м ${ }^{3}$ отходов. Відповідно енергетичній переробці підлягає до 1,0 млн м³ вуглецевовміщуючих відходів, що біологічно розкладаються. 3 цього обсягу за пропонованою нами технологією може бути отримано 157.000 т водню, річний дохід від продажу якого складе 62,8 млн дол. Бібл. 11, рис. 3, табл. 1.

Ключові слова: водень, тверді побутові відходи, акумуляція, піроліз, газифікація, органічний цикл Ренкіна.

\section{Список літератури}

1. Савчук С.Д. Почему Украина должна стимулировать развитие водорода. - https:// www.epravda.com.ua/rus/projects / greendeal / 2020 $/ 05 / 18 / 660480 /$

2. Armaroli N., Balzani V. The Hydrogen Issue. ChemSusChem. 2011, № 4. P. 21-36.

3. Водородные энергетические технологии : Материалы семинара лаборатории ВЭТ ОИВТ РАН.
Отв. ред. Д.О.Дуников. М. : ОИВТ РАН, 2017. Вып. 1. 190 с.

4. Sales D., Romero L.I., Solera R. Hydrogen production from the organic fraction of municipal solid waste in anaerobic thermophilic acidogenesis: Influence of organic loading rate and microbial content of the solid waste. Bioresource Technology. February 2013. Vol. 129. P. 85-91.

5. Jiunn-Jyi Lay, Young-Joon Lee, Tatsuya Noike. Feasibility of biological hydrogen production from 
organic fraction of municipal solid waste. Water Research, August 1999, Vol. 33, Iss. 11, P. 25792586.

6. Elsamadony M., Tawfik A. Potential of biohydrogen production from organic fraction of municipal solid waste (OFMSW) using pilot-scale dry anaerobic reactor. Bioresour Technol. 2015 Nov. Vol. 196. P. 9-16.

7. Shen Chen, Aihong Meng, Yanqiu Long, Hui Zhou, Qinghai Li Y., and Uo Zhang. TGA pyrolysis and gasification of combustible municipal solid waste. August 2015. Vol. 88, Iss. 3. P. 332-343.

8. Tae-Heon Kwak, Seungmoon Lee, Jin-Won Park, Sanjeev Maken, Young Done Yoo \& SangHouck Lee. Gasification of municipal solid waste in a pilot plant and its impact on environment. Korean $J$. Chem. Eng. 2006. Vol. 23, P. 954-960. https: / / doi.org/10.1007/s11814-006-0014-2/
9. Об оказании услуг по определению морфологического состава ТБО, которые образуются в жилой застройке г. Одессы : Отчет ООО «Украинский научно-исследовательский институт по разработке и внедрению коммунальных программ и проектов». Харьков, 2018.

10. Пат. 141908 U Укр., МПК (2006): С 01 В 3/02 (2006.01), С 08 J $11 / 00$. Спосіб виробництва водню з відходів сільськогосподарської діяльності. В.Я.Браверман, І.Г.Круш. Опубл. 27.04.2020, Бюл. № 8.

11. Пат. 115816 U Укр., МПК F $24 \mathrm{H} 7 / 02$ (2006.01). Акумулятор теплоти з фазовим переходом. В.І.Кушнерук, В.Я.Браверман, М.О.Букраба, Д.І.Челідзе. Опубл. 25.04.2017, Бюл. № 8.

Надійшла до редакції 17.09.2020

\footnotetext{
Браверман В.Я.', канд. техн. наук, Круш И.Б. ${ }^{1}$ Савчук С.Д. ${ }^{2}$ 1 ООО «Консалтингово-внедрениеский центр «Возобновляемые ресурсы», Одесса ул. Маршала Говорова, 10-б, 65059, Одесса, Украина,-е-таil: braverman@resources.odessa.иа ${ }^{2}$ Компания «Клиар Енерджи», Киевская область, Украина ул. Соборная, 2, с. Петропавловская Борщаговка, Киевская область, Украина, e-mail: sdsavchuk74@gmail.com
}

\section{Система производства водорода из органической части твердых бытовых отходов Одесского полигона}

Предлагаемая система производства водорода как энергоносителя для водородных энергетических технологий состоит из низкотемпературного пиролиза отходов, высокотемпературной газификации продуктов пиролиза, а также блока мембранного разделения синтезгаза на чистый водород и угарный газ. Высокая эффективность предлагаемой нами системы достигается за счет аккумуляции бросового экзотермического тепла пиролиза в материалах с фазовыми переходами, а также сжигания оксида углерода, полученного при разделении синтез-газа. Показано, что использование блоков аккумуляции вихідного тепла на основе материалов с фазовыми переходами в системах производства электрической энергии водородными топливными элементами позволяет существенно повысить КПД этих систем. На Одесский полигон твердых бытовых отходов в год поступает в зависимости от сезона от 2,5 до 3,0 млн м ${ }^{3}$ отходов. Соответственно энергетической переработке подлежит до 1,0 млн м ${ }^{3}$ углеродсодержащих биологически разлагаемых отходов. Из этого объема по предлагаемой нами технологии может быть получено 157.000 т водорода, годовой доход от продажи которого составит 62,8 млн долл. Библ. 11, рис. 3, табл. 1.

Ключевые слова: водород, твердые бытовые отходы, аккумуляция, пиролиз, газификация, органический цикл Ренкина. 